\title{
Voltage and frequency control of standalone wind-driven self-excited reluctance generator using switching capacitors
}

\author{
Joseph S. Sedky ${ }^{1}$, Haitham M. Yassin² ${ }^{*}$ D, H. H. Hanafy ${ }^{2}$ and Farouk Ismail ${ }^{2}$
}

\author{
${ }^{*}$ Correspondence: \\ haitham.yassin@cu.edu.eg \\ 2 Electrical Power \\ Engineering Department, \\ Faculty of Engineering, Cairo \\ University, Giza, Egypt \\ Full list of author information \\ is available at the end of the \\ article
}

\begin{abstract}
This paper presents a methodology for voltage and frequency $(V-f)$ control of a standalone wind-driven self-excited reluctance generator (WDSERG). The methodology is based on proposing two different compensation configurations using two switching capacitors (short-shunt and long-shunt compensation) for $(V-f)$ control. The dynamic and steady-state performances of the two configurations are discussed under different operating conditions: wind speeds, load currents and power factors. This analysis is done by developing a complete dynamic model of WDSERG including the excitation capacitors and load. Therefore, complete equivalent circuits are proposed. The values of capacitors are controlled by adjusting the duty cycle of $\mathrm{H}$-bridge circuits with $\mathrm{PI}$ controllers. To validate the proposed configurations and their dynamic models and equivalent circuits, simulation results for a 1.5-kW standalone WDSERG and experimental results for $0.2 \mathrm{~kW}$ reluctance generator driven by a DC motor, emulating the wind turbine, are carried out. The results show a significant enhancement in voltage and frequency regulation with the selected optimal capacitances for each configuration; however, short-shunt compensation is the preferred configuration as it controls the output voltage and frequency with minimum values of capacitances and minimum required duty variation.
\end{abstract}

Keywords: Self-excited reluctance generator, Voltage and frequency control, Shortshunt and long-shunt compensations, Variable switching capacitor

\section{Introduction}

As a viable renewable alternative, wind energy conversion system (WECS) is becoming popular due to the ever-increasing energy demand and global warming $[8,29]$. A review of maximum power point tracking (MPPT) technologies for WECSs with various control schemes and generators is presented in [15]. According to grid connection, WECS schemes are classified as standalone or grid connected $[6,12]$. During standalone operation, the output load voltage amplitude and frequency should be controlled, while in grid connection operation, the active and reactive powers delivered to grid are controlled [18]. The most suitable selections for grid-connected wind turbine are permanent magnet synchronous generator (PMSG) and doubly fed induction generator (DFIG). As

(c) The Author(s) 2021. This article is licensed under a Creative Commons Attribution 4.0 International License, which permits use, sharing, adaptation, distribution and reproduction in any medium or format, as long as you give appropriate credit to the original author(s) and the source, provide a link to the Creative Commons licence, and indicate if changes were made. The images or other third party material in this article are included in the article's Creative Commons licence, unless indicated otherwise in a credit line to the material. If material is not included in the article's Creative Commons licence and your intended use is not permitted by statutory regulation or exceeds the permitted use, you will need to obtain permission directly from the copyright holder. To view a copy of this licence, visit http://creativeco mmons.org/licenses/by/4.0/. 
many remote locations, the grid disconnection motivates the option of utilizing standalone wind turbine with the use of self-excited induction and reluctance generators $[10$, 36].

In both direct-driven mode and with single- or multistage gearbox, PMSG wind system could be more efficient than DFIG system [38]. High torque density, reduced rotor thermal stress and high energy conversion efficiency are the key benefits of using PMSG due to the existence of the PM in the rotor [16]. Cost of PM materials, PM demagnetization at high temperature and cogging torque effects are the major PMSG using limitations [22]. However, due to dependance of PMSG output voltage and frequency on wind speed, PMSG cannot be connected directly to grid; therefore, a power conversion system should be used to adjust the injected grid power. For variable speed, fixed pitch WECSs, torque and speed control strategies are analyzed and presented in [13], which would increase robustness and reliability of the generator.

Owing to its lowest cost, robustness, less converter rating requirements and no need for a DC source for excitation, DFIG wind turbine is the most commonly used one in the market [17]. However, the brushes and slip rings existence on the DFIG rotor require regular maintenance. Therefore, the remote and offshore application of DFIG is less reliability and more cost [24].

The concept of DFIG normal operation when connected to the grid is presented in [21]. Maximum active power extraction and reactive power control are discussed; however, the concept and enhancement techniques for fault ride through, crowbar protection, torque pulse compensation and stator unbalance are established.

The target in standalone WECS is to sustain voltage and frequency under changing wind speeds and loads. However, the DFIG is inappropriate for small standalone applications where low cost is the most priority due to its great size, high cost and massive complexity related to the DFIG design, assembly and control [28].

The most important factors in the generator's selection are cost and control simplicity. In this view, alternatives for PMSG and DFIG are self-excited generators due to their relative low cost. Therefore, in recent years, there is significant increase in the research and development of SEIG and SERG for standalone systems. The primary advantages of a SEIG are brushless construction with squirrel-cage rotor, rugged and robust rotor, no DC supply for excitation, small size and less maintenance cost. In addition, it has better transient performance [34].

For isolated SEIG, the steady-state performance is analyzed and studied taking into consideration the machine core losses and their variation with air gap flux. This study is obtained with a SEIG feeding a balanced inductive load [20]. Firstly, the machine must operate in saturation region for a stable operation of SEIG. Minimum excitation capacitance required at no load to control the generator terminal voltage at its desired constant value is calculated through this study. Besides, the study gives the required capacitance value to keep the generator terminal voltage at constant value under wind speed, load impedance and power factor variations. The variable excitation capacitance value is provided by fixed capacitor thyristor-controlled reactor. In [5], the continuously controlled shunt capacitor connected to SEIG is utilized in the proposed SEIG. The variable excitation capacitor could be done by employing back-to-back connected IGBT switches across the fixed excitation capacitors to regulate the terminal voltage. The results proved 
that over wide variety of loads and speed changes, a constant generator terminal voltage is achieved by the controlled shunt capacitor of SEIG and hence is a reliable and cost-effective.

SEIG simplicity makes it relatively inexpensive and popular in isolated WECS applications. In addition, it is self-protected counter to extreme overload and short-circuit possibilities [7]; however, an attendant needs for voltage and frequency stabilizing circuits to overcome poor regulation in generator output voltage and frequency with variable prime-mover speed and load. This will increase the installation cost [33].

The SERG with wind energy is practically utilized in electric power generation [31]. SERG is commonly used with standalone wind turbine. However, it can be also utilized in gird-connected wind turbine system. When SERG is connected to an isolated load, a capacitor bank should be connected to the generator terminals to achieve successful excitation. In case of grid-connected wind system, a local capacitor bank connected at the generator terminals or leading power factor loads could be the methodology for getting the required excitation [32]. In [9], the criteria of selecting the suitable excitation capacitance for a SERG driven by regulated turbine (constant frequency) are presented. By applying this methodology, AC constant output terminal voltage would be produced under changing the connected load.

Since the most works are based on PMSG and SEIG for standalone WECS, the use of SERG has paucity literature with standalone WECS. Besides having almost all the induction generator advantages, the frequency of SERG output voltage could be directly adjusted through controlling the rotor speed [30]. The performance characteristics of SERGs have been determined by different proposed methods [23]. In [14], the two-axis theory is used to study the steady-state model of SERG, which supplies an inductive load. Core losses are neglected, and magnetic saturation is assumed to be confined to the direct axis and is accounted for by a variable direct-axis magnetizing reactance. The theory developed also enables a direct computation of the minimum capacitance required to initiate self-excitation for a given value of load impedance. The value of minimum load resistance, connected to the stator's terminals of SERG in standalone mode, could be determined by eigenvalue and eigenvalue sensitivity [35]. The effect on the SERG performance due to variation in excitation capacitor, wind speed, and load is introduced in [4]. Moreover, under open-circuit, resistive and pure inductive loads, expressions for the cutoff speed value are also derived and presented in [3]. In [25], the effect of rotor cage on the performance of SERG supplying loads of different power factors is presented. The cageless SERG can only deliver less than half the rated power, while more than twothirds of the rated power could be produced by SERG with a cage. This is due to the inability of the cageless machine to excite at capacitance values high enough to circulate the rated current in the machine windings. New methods of studying the machine characteristics are based on equations between SERG parameters and external load. Then, comparisons between these methods and conventional methods are held for machine parameter measurements [11].

A mathematical model that can successfully predict the dynamic performance of single-phase SERG is presented in [2]. This model is used to study the dynamic stability of the generator under different operating conditions. The minimum excitation capacitance required for single-phase SERG is affected by the speed fluctuations [1]. Due to its 
poor reactance ratio, poor power factor is one of the major disadvantages of synchronous reluctance machine with simple salient rotor. Improving the performance characteristics, by improving the effective reactance ratio, can be achieved by splitting the stator winding to two three-phase windings. The grid is connected to one-stator winding, and the other winding is attached to a balanced capacitor bank [26]. In [27], dual winding reluctance generator with mixed poles is analyzed to determine its performance characteristics.

In this paper, two different capacitors connections (short- and long-shunt compensation configuration) for a WDSERG are presented. Dynamic models and equivalent circuits for each configurations of compensation are developed. For most practical application, it is always required to obtain efficient energy production and constant output voltage and frequency from a WDSERG. Regulating voltage and frequency of SERG are obtained by using shunt and series switched capacitors at a certain value under different wind speeds and/or loads. A selection method of optimal capacitor values, to maintain an efficient energy production, which can be implemented in a controller, is presented. The value of each capacitor is controlled by adjusting the duty cycle of $\mathrm{H}$-bridge circuit with PI controllers. PI controller gains are selected using the trial-and-error method to get the best response. Comparison between capacitor values in the two configurations is obtained to determine which one is preferable. To validate the theoretical analysis and the model of the two different compensation configurations, single-point experiments for a given value of shunt capacitor, series capacitor and load impedance were performed in the laboratory.

\section{System configuration and modelling}

Figure 1 shows the schematic of WDSERG system connected to an isolated load. The system consists of unregulated wind turbine coupled with the reluctance generator through a gearbox. The generator output voltage and frequency are fluctuating with wind speed changing and load variation. So, two capacitors, connected in series and shunt, are used to regulate the output voltage and frequency. The two compensation capacitors could be connected in two different configurations. The two configurations are short-shunt and long-shunt compensations as shown in Fig. 1.

\section{Wind turbine model}

The wind turbine output mechanical power can be defined by [37]:

$$
\begin{aligned}
& P_{m}=\frac{1}{2} C_{p}(\beta, \lambda) \rho A v_{w}^{3} \\
& \lambda=\frac{\omega_{t} R}{v_{w}}
\end{aligned}
$$

Figure 2 depicts the turbine output power as a function of the rotor speed for different wind speeds with the blade pitch angle $\beta=0^{\circ}$. 


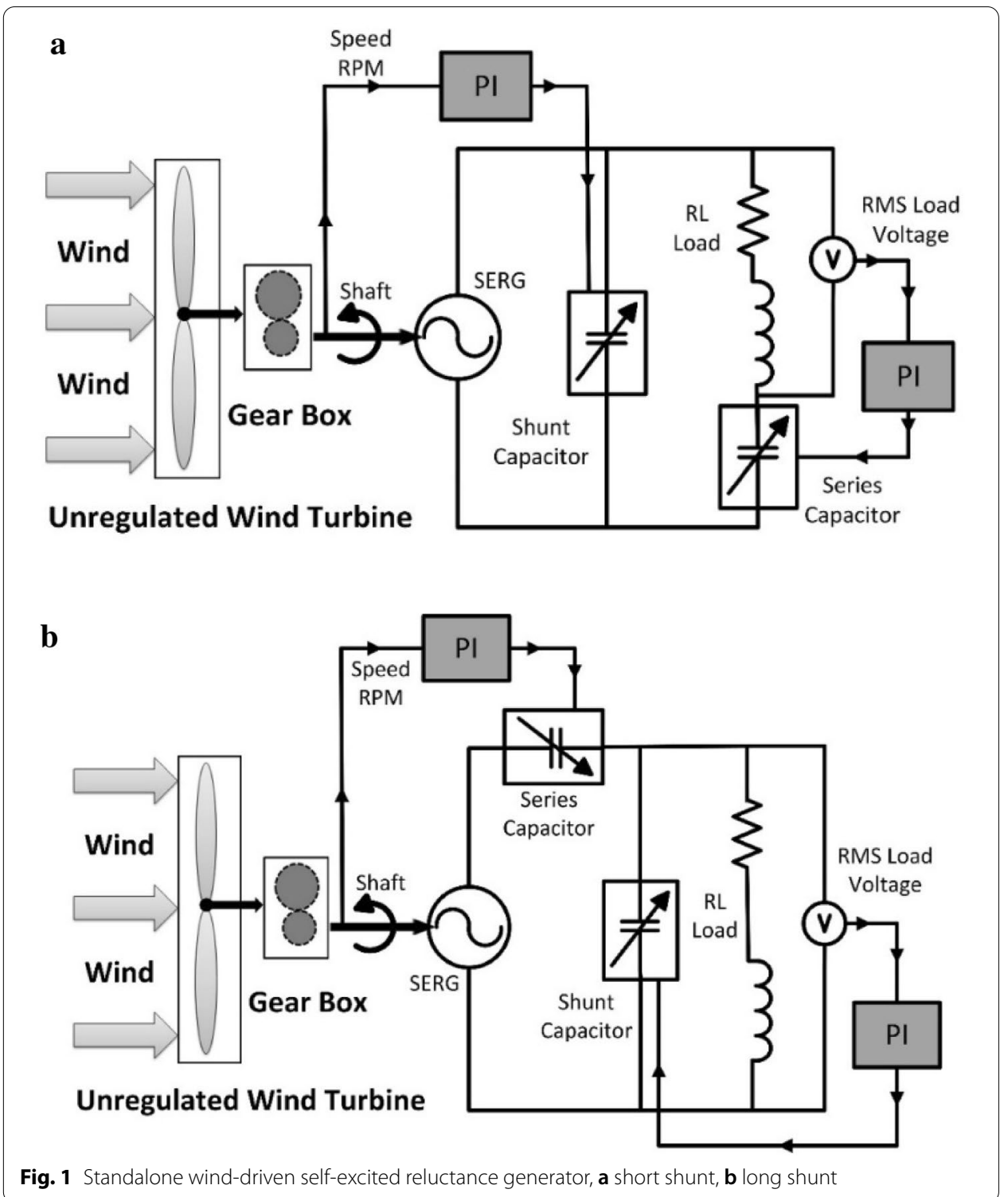

\section{Dynamic model of SERG at no load}

The self-excitation of the SERG is done using shunt capacitor. The machine must operate in the saturation region, and sufficient rotor speed and residual flux are required to initiate the self-excitation of SERG, and then, voltage starts building up which will be limited by the core saturation at steady state.

The following assumptions are taken in consideration in steady state and dynamic models:

1. MMF and flux density distributions are sinusoidal

2. Balanced operation of SERG

3. Neglect core losses 


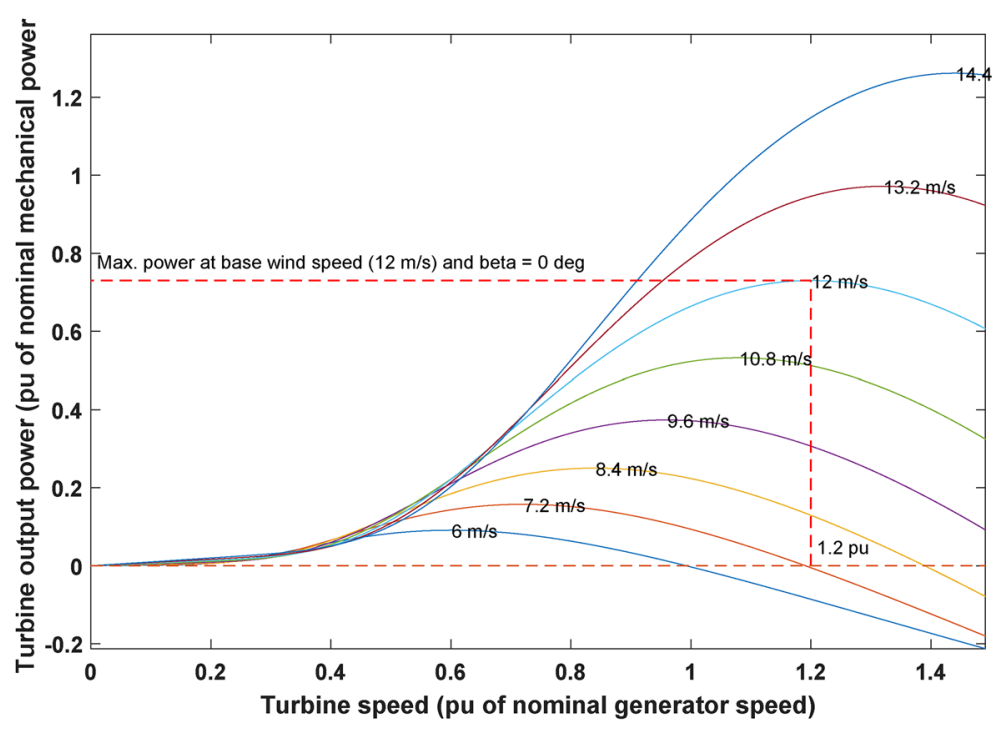

Fig. 2 Wind turbine power characteristics $\left(\beta=0^{\circ}\right)$

4. Magnetic saturation in the $d$-axis only

The current equations for SERG, without damper windings, in the $d-q$ rotor reference frame are given by [19]:

$$
\begin{aligned}
& p i_{d s}=\frac{-\omega_{o}}{X_{d s}}\left[v_{d s}+R_{s} i_{d s}-\frac{\omega_{r}}{\omega_{o}} X_{q s} i_{q s}\right] \\
& p i_{q s}=\frac{-\omega_{o}}{X_{q s}}\left[v_{q s}+R_{s} i_{q s}+\frac{\omega_{r}}{\omega_{o}} X_{d s} i_{d s}\right]
\end{aligned}
$$

where the current equations, in the $d-q$ rotor reference frame, of the shunt capacitor are described by [19]:

$$
\begin{aligned}
& p v_{d s}=\omega_{r} v_{q s}+\frac{i_{d s}}{C} \\
& p v_{q s}=-\omega_{r} v_{d s}+\frac{i_{q s}}{C}
\end{aligned}
$$

The electromagnetic torque of the generator can be given by:

$$
T_{\mathrm{e}}=\frac{3}{2} P\left[\lambda_{d s} i_{q s}-\lambda_{q s} i_{d s}\right]
$$

where the stator flux linkages in the $d-q$ axes are given by: 


$$
\begin{aligned}
& \lambda_{d s}=-L_{d s} i_{d s} \\
& \lambda_{q s}=-L_{q s} i_{q s}
\end{aligned}
$$

The mechanical equation of the generator can be written as:

$$
\omega_{r}=\frac{P}{J}\left(T_{\mathrm{pm}}-T_{\mathrm{e}}\right)
$$

When the SERG operates at no load, a closed-form solution for minimum capacitor value $\left(C_{\min }\right)$ could be obtained if the core loss is neglected [14].

$$
C_{\min }=\frac{2}{\omega_{r}\left(\left(X_{d u n}+X_{q}\right) \pm \sqrt{\left(X_{d u n}-X_{q}\right)^{2}-4 R_{s}^{2}}\right)}
$$

When the armature resistance is very small,

$$
X_{c \max }=\frac{1}{\omega_{r} C_{\min }}=X_{d u n}
$$

This means that the machine will self-excite if $X_{c}$ is less than $X_{d u n}$.

\section{Dynamic model of short-shunt compensation with load}

The mathematical model of the short-shunt compensation configuration of WDSERG shown in Fig. 1a can be derived using the equivalent circuit of the system shown in Fig. 3. The current equations for reluctance generator, without damper winding, in the $d-q$ rotor reference frame are same as Eqs. (3) and (4). The differential equations of the shunt capacitor with parallel-connected load in the $d-q$ rotor reference frame are described by:

$$
\begin{aligned}
& p v_{d s}=\omega_{r} v_{q s}+\frac{i_{d s}-i_{d l}}{C_{s h}} \\
& p v_{q s}=-\omega_{r} v_{d s}+\frac{i_{q s}-i_{q l}}{C_{s h}}
\end{aligned}
$$

The differential equations, in the $d-q$ rotor reference, of the load are given by:

$$
\begin{aligned}
& p i_{d l}=\frac{v_{d s}-R_{l} i_{d l}}{L_{l}}+\omega_{r} i_{q l}-\frac{v_{c d}}{L_{l}} \\
& p i_{q l}=\frac{v_{q s}-R_{l} i_{q l}}{L_{l}}-\omega_{r} i_{d l}-\frac{v_{c q}}{L_{l}}
\end{aligned}
$$

The differential equations, in the $d-q$ rotor reference, of series capacitor are illustrated as: 
$\mathbf{a}$

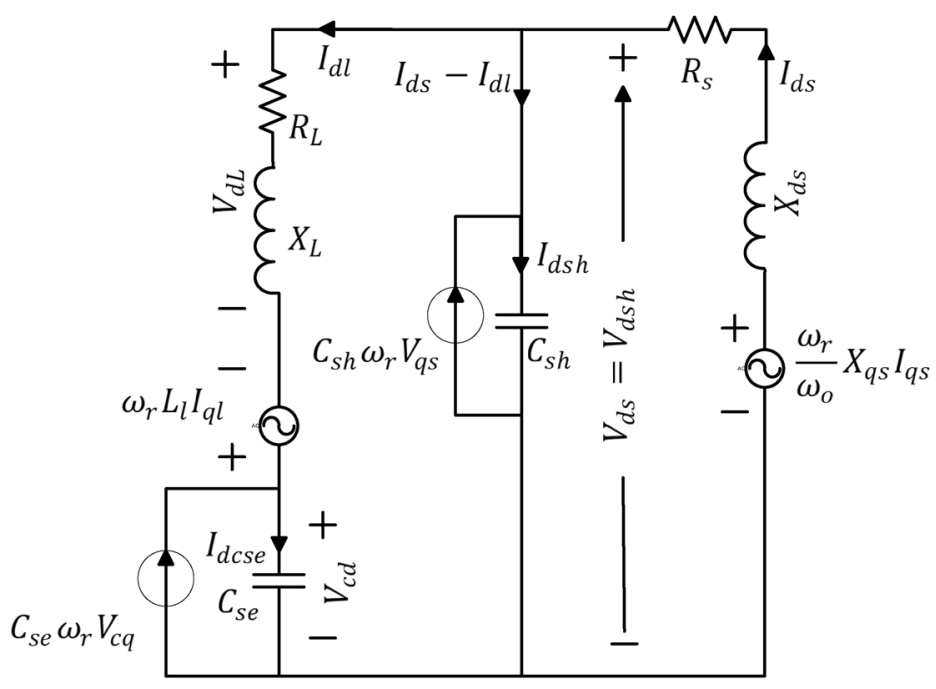

b

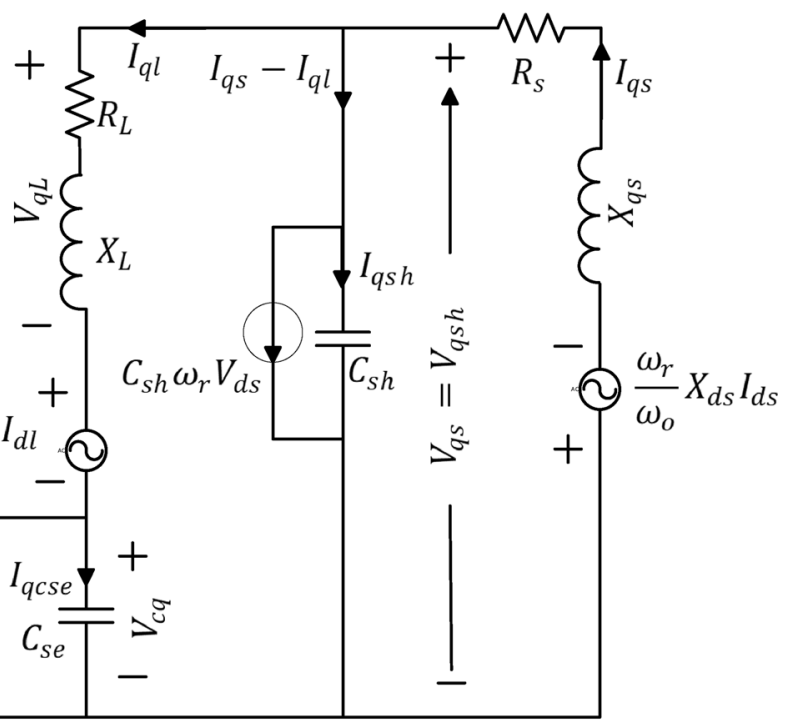

Fig. 3 Dynamic equivalent $d$ - $q$ circuit for short-shunt compensation, a $d$-axis circuit, $\mathbf{b}$-axis circuit

$$
\begin{aligned}
& p v_{c d}=\omega_{r} v_{c q}+\frac{i_{d l}}{C_{\mathrm{se}}} \\
& p v_{c q}=-\omega_{r} v_{c d}+\frac{i_{q l}}{C_{\mathrm{se}}}
\end{aligned}
$$

\section{Dynamic model of long-shunt compensation with load}

The equivalent circuit shown in Fig. 4 is used to derive the mathematical model of the long-shunt compensation configuration of WDSERG. As given in Eqs. (3) and (4), the cageless reluctance generator has current equations in the $d-q$ rotor reference frame like short-shunt compensation. 

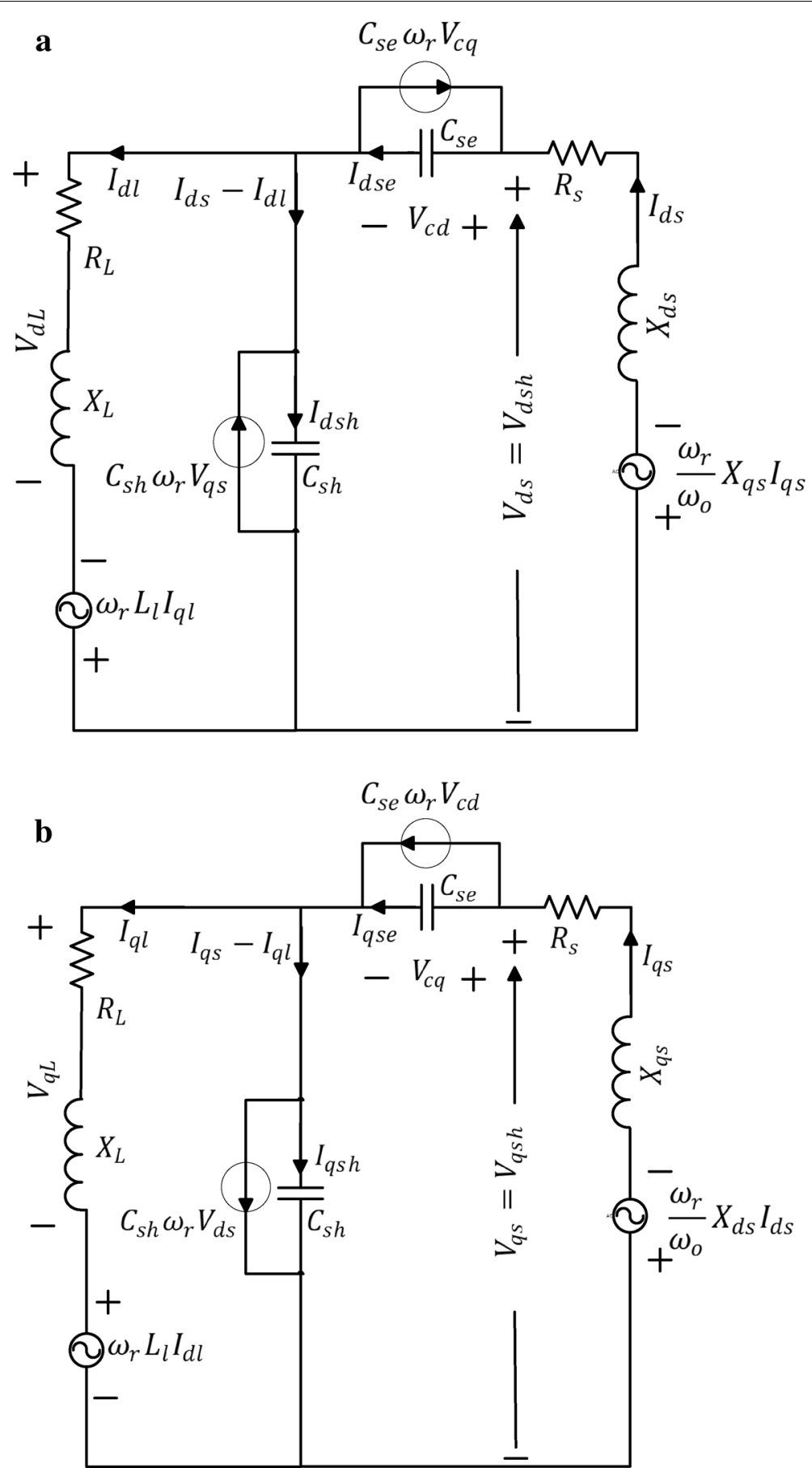

Fig. 4 Dynamic equivalent $d$ - $q$ circuit for long-shunt compensation, a $d$-axis circuit, $\mathbf{b} q$-axis circuit

Where the differential equations, in the $d-q$ rotor-reference frame, of the shunt capacitor are described by:

$$
p v_{d l}=\omega_{r} v_{q l}+\frac{i_{d s}-i_{d l}}{C_{\mathrm{sh}}}
$$




$$
p v_{q l}=-\omega_{r} v_{d l}+\frac{i_{q s}-i_{q l}}{C_{\mathrm{sh}}}
$$

The differential equations, in the $d-q$ rotor-reference frame, of the load are given by:

$$
\begin{aligned}
& p i_{d l}=\frac{v_{d l}-R_{1} i_{d l}}{L_{1}}+\omega_{r} i_{q l} \\
& p i_{q l}=\frac{v_{q l}-R_{1} i_{q l}}{L_{1}}+\omega_{r} i_{d l}
\end{aligned}
$$

The differential equations of series capacitor in $d-q$ rotor-reference frame are illustrated as:

$$
\begin{aligned}
& p v_{c d}=\frac{i_{d s}}{C_{\mathrm{se}}}+\omega_{r} v_{c q} \\
& p v_{c q}=\frac{i_{q s}}{C_{\mathrm{se}}}-\omega_{r} v_{c d}
\end{aligned}
$$

\section{Determination of optimal capacitors}

In standalone WDSERG system, the output stator voltage and frequency are controlled to certain levels by variable three-phase shunt and series capacitors bank. The capacitance variation can be accomplished by utilizing switched capacitor principle, which is a three-phase capacitors bank connected to the reluctance generator through a threephase inverter, and the capacitance value changes with duty ratio of the switches as follows:

$$
\begin{aligned}
& C_{e}=\frac{C}{(2 d-1)^{2}} \\
& d=\frac{t_{1}}{T}
\end{aligned}
$$

where $C_{e}$ is effective capacitance value, $C$ is fixed capacitance value, $d$ is duty ratio of the switches, $t_{1}$ is the on-time period and $T$ is the total switching time. To keep the output voltage and frequency of WDSERG at certain value, two PI controllers are used to control the inverter switches for adjusting the desired value of series and shunt capacitors. The controller gains tuning is achieved via using the trial-and-error method.

Table 1 SERG parameters

\begin{tabular}{llllll}
\hline Power $(\mathrm{kW})$ & Voltage $(\mathrm{V})$ & Speed $(\mathrm{rpm})$ & Rs $(\Omega)$ & $X_{q}(\Omega)$ & Xd $(\Omega)$ \\
\hline 1.5 & 415 & 1500 & 10.12 & 49.1 & 181.8 \\
\hline
\end{tabular}




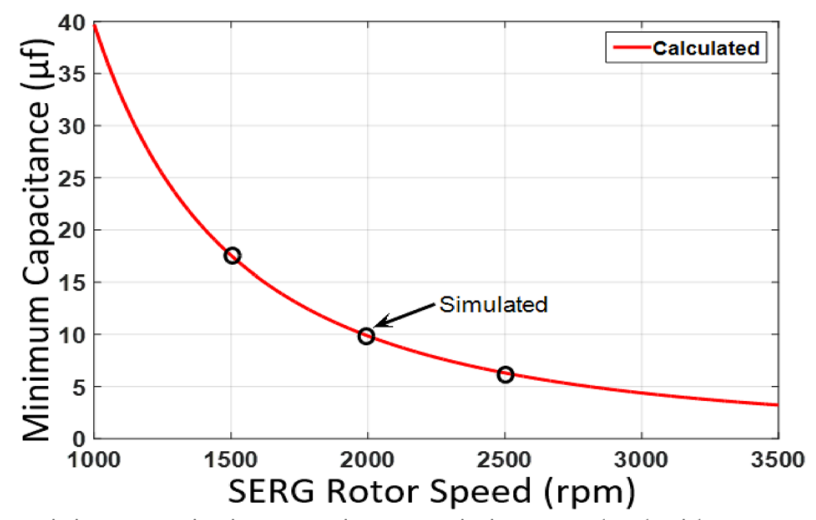

Fig. 5 Minimum excitation capacitance variation at no load with SERG speed

\section{Simulation results}

The performance of a 1.5-kW WDSERG with series and shunt capacitors is examined using MATLAB/Simulink. Table 1 gives the SERG parameters used in the simulation. The simulation results are obtained with variable wind speeds, load impedances and power factor. The output load voltage is controlled at $220 \mathrm{~V}$ with a desired output load frequency at $50 \mathrm{~Hz}$.

The corresponding value of $X_{d s}$ for each value of $d$-axis current $i_{d s}$ is obtained from magnetization curve, which are represented by $6^{\text {th }}$-order polynomial equation as shown:

$$
X_{d s}=-0.002839 i_{d s}^{6}+0.10299 i_{d s}^{5}-1.1798 i_{d s}^{4}+5.5572 i_{d s}^{3}-7.9918 i_{d s}^{2}-30.4452 i_{d s}+182.1
$$

\section{Minimum capacitor required for SERG at no load}

At no load, the value of minimum capacitance required to build up the generator terminal voltage depends on the generator output frequency, i.e., rotor speed, variation as shown in Eq. (11). Furthermore, using the differential equations stated in the previous sections, a dynamic model of SERG at no load and constant speed is created using MAT$\mathrm{LAB} /$ Simulink. PI controller is used to control the speed of generator by toque variation. The excitation capacitance value is decreased gradually until the terminal voltage of SERG disappeared and minimum capacitor value is recorded. The relation between minimum capacitance and the SERG rotor speed, which is shown in Fig. 5, can be obtained by repeating the above procedure for other generator speeds. A good agreement between the calculate and simulation results is shown in Fig. 5, which provides a straightforward validation of the dynamic model of SERG and the mathematical study presented in Eq. (11) to determine the minimum capacitor for output voltage generation.

\section{Optimal capacitance required with variable load impedance for WDSERG}

The study is performed for two configurations under variable load characteristic with constant power factor 0.9 lag and constant wind speed equal to $8.5 \mathrm{~m} / \mathrm{s}$. The generator will run at no load for $25 \mathrm{~s}$; then, a lagging power factor load ( $R=300 \Omega$ and $L=450$ $\mathrm{mH}$ ) is connected to the generator terminal. Finally, the load is changed to $R=200 \Omega$ 
a

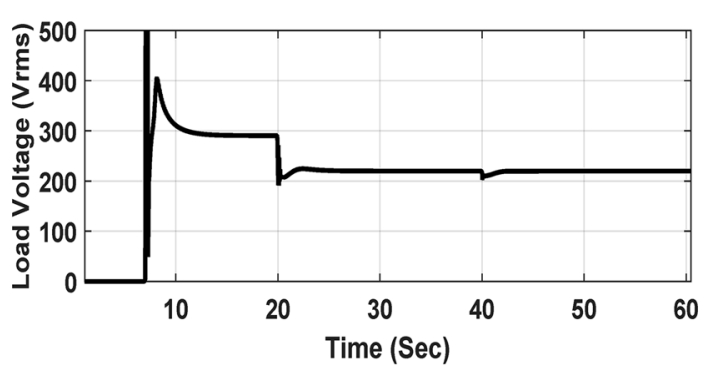

b

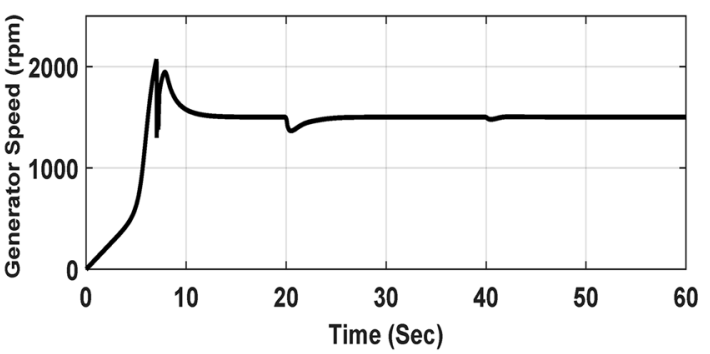

C
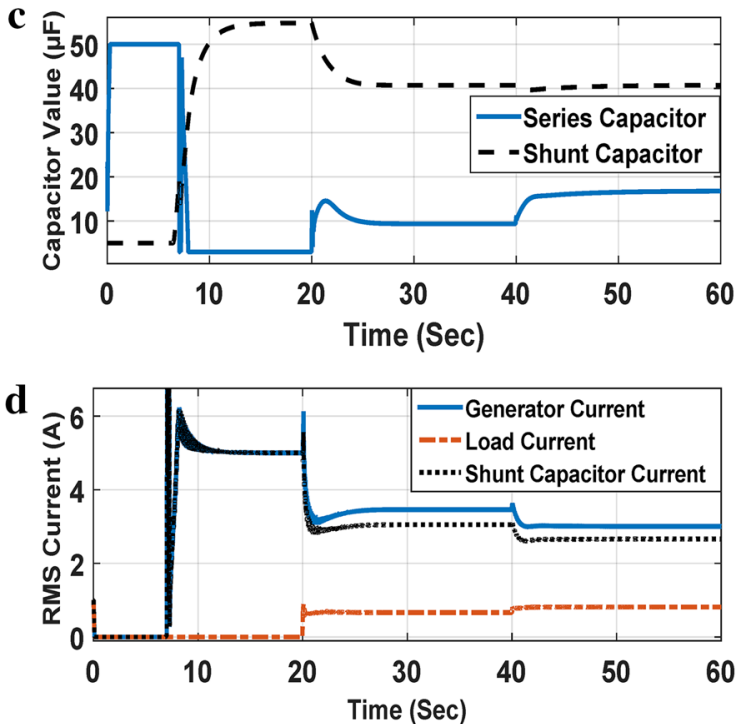

e

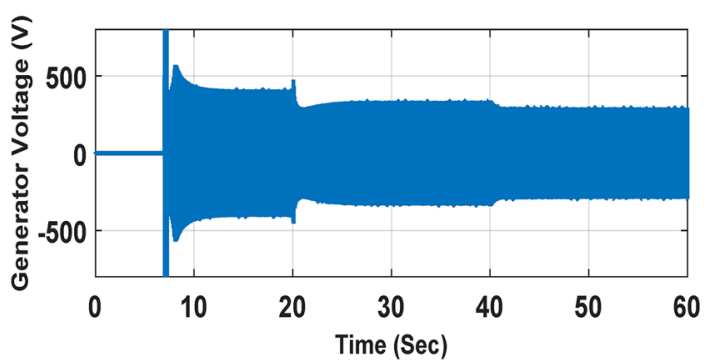

Fig. 6 Short-shunt compensation under load variation, a load voltage, $\mathbf{b}$ generator speed, c shunt and series capacitors value, $\mathbf{d}$ generator, shunt capacitor and load currents, e generator voltage

and $L=300 \mathrm{mH}$ at $\mathrm{t}=45 \mathrm{~s}$. Under no-load condition, the two configurations gradually build their voltages.

Figure 6 shows the simulation results for short-shunt compensation with variable load impedance. In this configuration, the shunt capacitor is used to control the output 
frequency at $50 \mathrm{~Hz}$ and the series one is used to control the output load voltage at 220 $V$ rms. Under no-load condition, the generator voltage builds up and the voltage level increased in no-load period to $240 \mathrm{~V}$ because there is no control on voltage level due to disconnection of series capacitor as shown in Fig. 6a. At any load current increasing instant, there will be an increase in the generator current, which will increase the voltage drop on the stator impedance of the generator. Therefore, there is a drop in the load voltage, with each load current increasing, before the voltage controller takes action and restores the load voltage again to its desired value by changing the series capacitor value. Figure $6 \mathrm{~b}$ shows the rotor speed; it is noticed that there is a decrease in the speed (undershoot) with each load current increasing step because of the increase in generator current; therefore, the load torque on the turbine is increased. So, the speed control will decrease the shunt capacitor value as shown in Fig. 6c. The reduction of the shunt capacitor will decrease the shunt capacitor current, which will decrease the overall generator current. The decrease in the generator current leads to decrease generator losses and the rotor speed increases across the wind turbine characteristics shown in Fig. 2. The rotor speed increases until the summation of the load power and generator losses are equal to the value before the load variation and the rotor speed restore its desired value at $1500 \mathrm{rpm}$.

Figure $6 \mathrm{c}$ shows also the required series capacitance value to maintain the load voltage constant. At no load, it is observed that the series capacitor value reaches its maximum limit as it is not connected in this period. The change in generator, shunt capacitor and load currents with load current increasing is shown in Fig. $6 \mathrm{~d}$. The generator voltage value depends on the reactive power from series and shunt capacitor that build field in SERG. Therefore, the reduction in shunt capacitor value will cause decrease in shunt capacitor current, reactive power supplied to the generator, and hence, generator voltage decreases as shown in Fig. 6e.

In long-shunt compensation, the series capacitor is used to control the output frequency at $50 \mathrm{~Hz}$, and the shunt one is used to control the output load voltage at $200 \mathrm{~V}$. In Fig. $7 \mathrm{a}$, there is a reduction in load voltage with increasing the load current until the controller decreases shunt capacitor value in order to decrease shunt capacitor current and generator current. As a result, the voltage drop on series capacitor and stator impedance will decrease so the load voltage will increase again. Unlike short-shunt compensation, the load voltage can be controlled even in no-load condition because the shunt capacitor is always connected to the generator.

In Fig. 7b, it observed that the increase in load current would result in increased speed. The generator speed can be controlled at $1500 \mathrm{rpm}$ with increasing loading current by increasing the capacitance of the series capacitor as shown in Fig. 7c.

Using series capacitor, the wind turbine output power can be controlled to adjust speed again. The value of shunt capacitor should be decreased to maintain the output voltage at $200 \mathrm{~V}$ as shown in Fig. 7c as increasing the load current connected to SERG would reduce load voltage. Figure $7 \mathrm{~d}$ shows the change in generator, shunt capacitor and load currents with load current increasing. Furthermore, there will be drop in generator voltage due to decrease in shunt capacitor value as shown in Fig. 7e. This decease results in drop in reactive power supplied from shunt capacitor that represents the field in SERG. 
$\mathbf{a}$

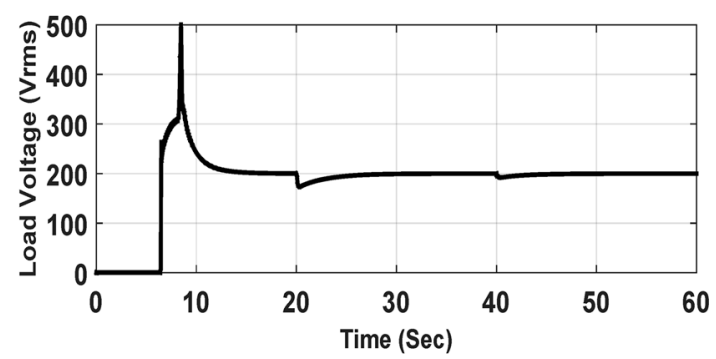

b

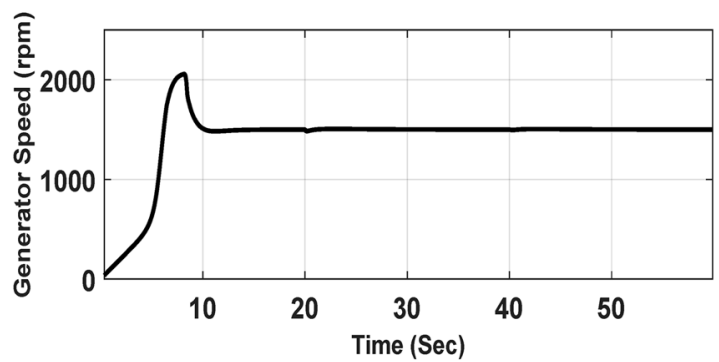

c

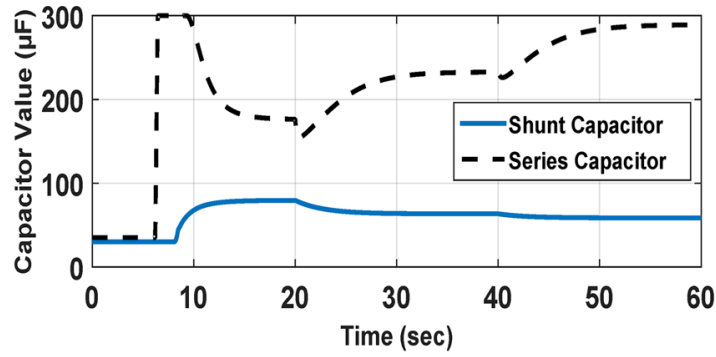

d

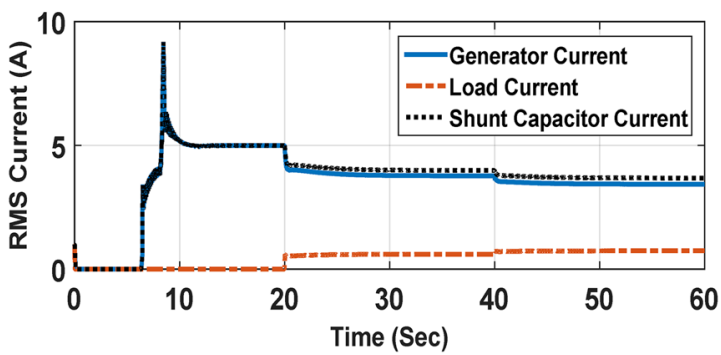

e

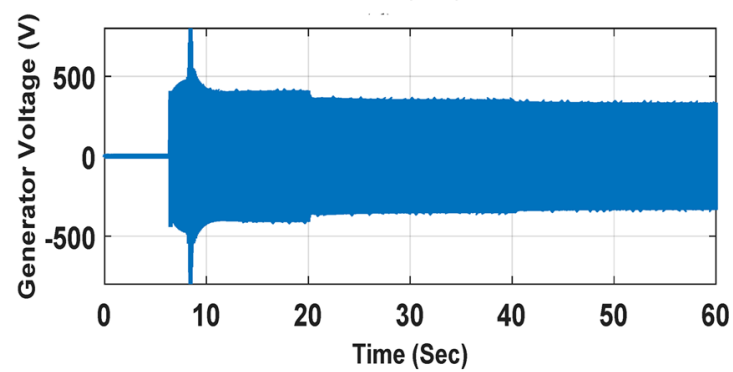

Fig. 7 Long-shunt compensation under load variation, a load voltage, $\mathbf{b}$ generator speed, c shunt and series capacitors value, $\mathbf{d}$ generator, shunt capacitor and load currents, e generator voltage

It can be noticed that generator and load currents in two configurations are the same. However, long-shunt compensation configuration yielded higher-shunt capacitor current and required higher capacitors value. Hence, short-shunt configuration is a preferable choice. 
a

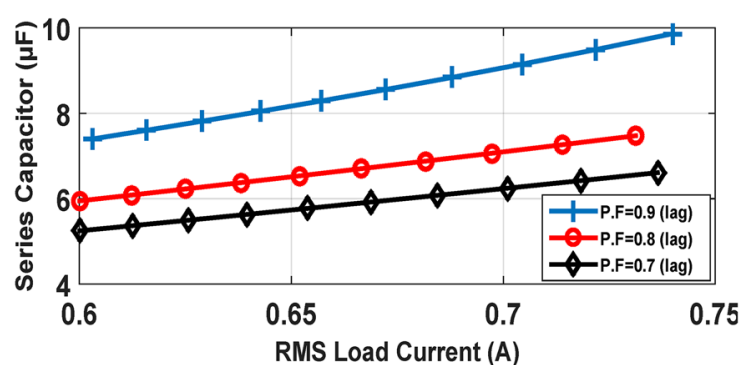

b

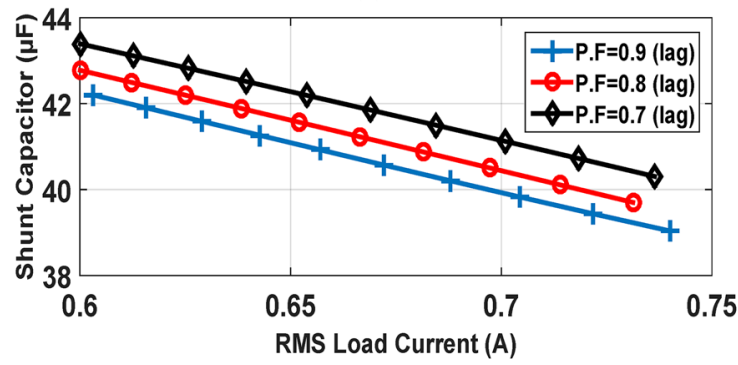

c

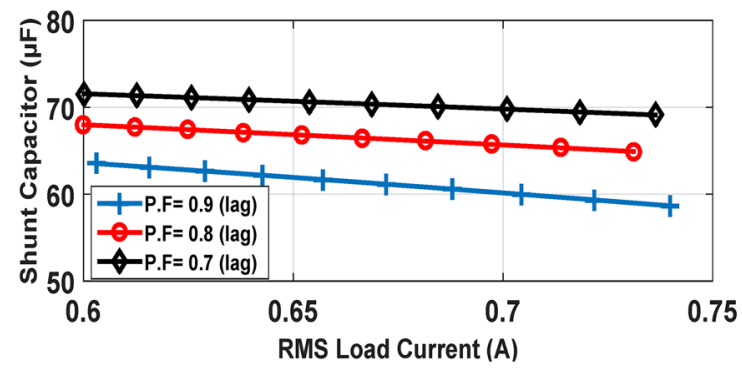

d

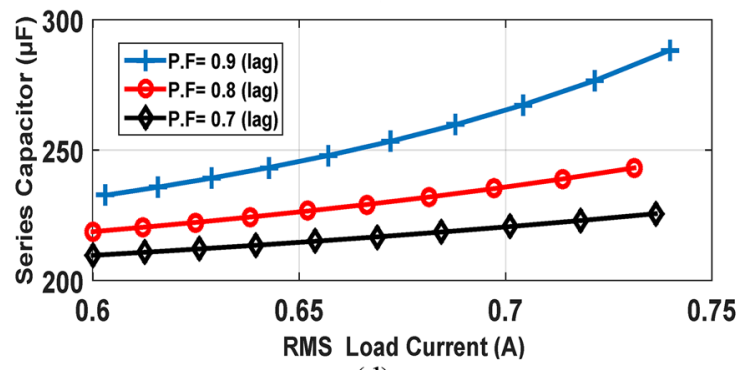

Fig. 8 Capacitor's values under load current and power factor variation, a series capacitor for short shunt, b shunt capacitor for long shunt, $\mathbf{c}$ shunt capacitor for short shunt, $\mathbf{d}$ series capacitor for long shunt

\section{Optimal capacitance required under variable load current and lagging power factor for WDSERG}

Series and shunt capacitors are used to achieve constant voltage level in short- and longshunt compensation, respectively. In case of short-shunt compensation, series capacitor value is directly proportional to loading current and power factor. The increase in the capacitor value, with increased loading conditions, is large with higher power factor as shown in Fig. 8a.

For long-shunt compensation, Fig. 8b shows the relation between shunt capacitor value and loading current. Generally, for constant output voltage, the more increase in 
a

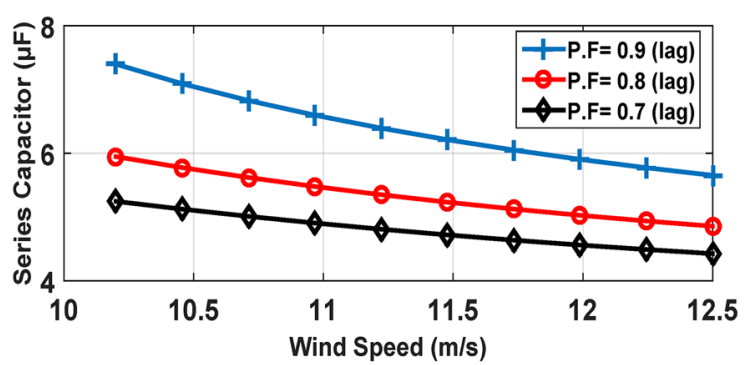

b

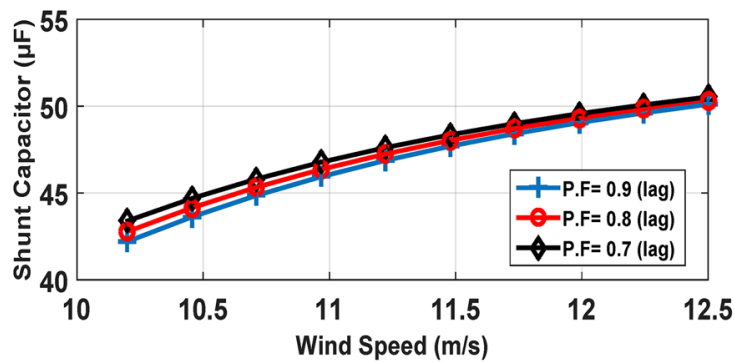

c

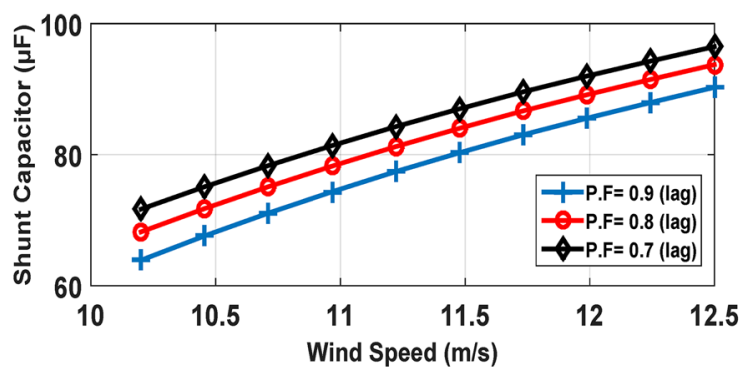

d

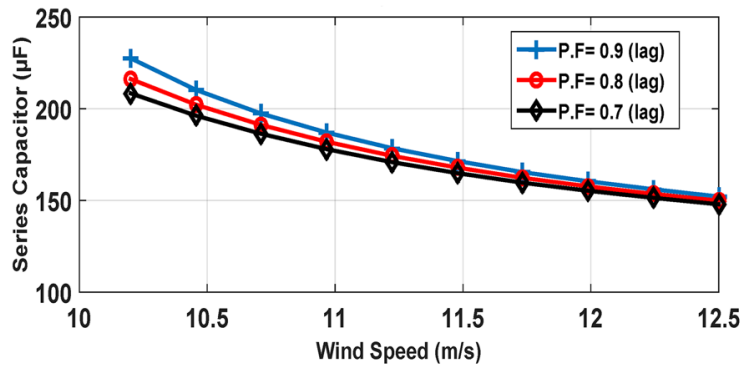

Fig. 9 Capacitors' values under wind speed and power factor variation, a series capacitor for short shunt, b shunt capacitor for long shunt, c shunt capacitor for short shunt, $\mathbf{d}$ series capacitor for long shunt

loading current and power factor, the less capacitance required. There will be change in speed when the load is increased as discussed in previous section and controllers will take actions to maintain speed at a desired level. Figure 8c, d shows shunt and series capacitors required to adjust frequency at $50 \mathrm{~Hz}$ in the short- and long-shunt compensations, respectively. In short-shunt compensation configuration, the required shunt capacitor value to adjust speed is inversely proportional to load current and power factor. On the other hand, series capacitor value has a direct relationship with the load current and power factor in long-shunt compensation configuration. 


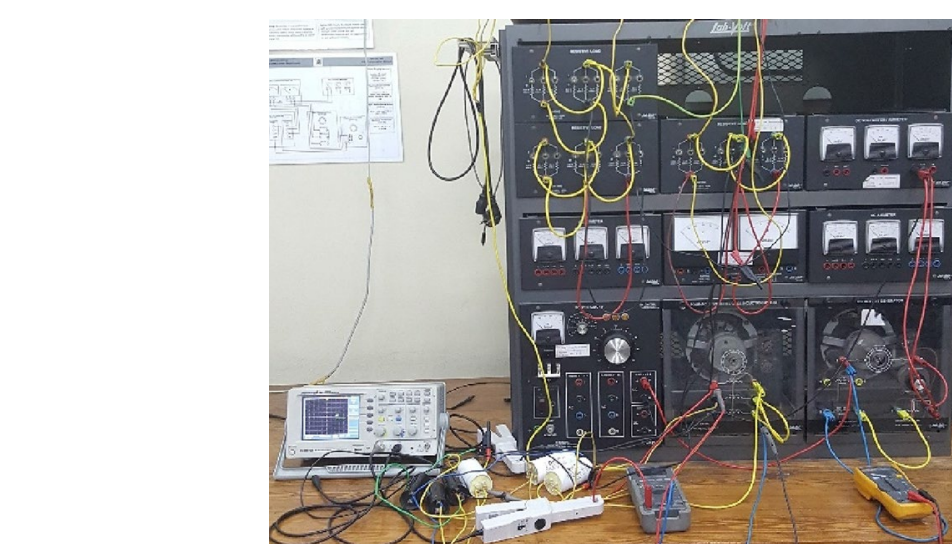

Fig. 10 The hardware setup layout

Table 2 Parameters of SERG used in the hardware work

\begin{tabular}{ll}
\hline Parameters & Values \\
\hline Stator resistance & $19.5 \Omega$ \\
Stator leakage inductance & $0.0339 \mathrm{H}$ \\
$d$-axis mutual inductance & $1.006 \mathrm{H}$ \\
$q$-axis mutual inductance & $0.437 \mathrm{H}$ \\
Rotor $d$-axis leakage inductance & $0.175 \mathrm{H}$ \\
Rotor q-axis leakage inductance & $0.079 \mathrm{H}$ \\
Rotor $d$-axis resistance & $9 \Omega$ \\
Rotor q-axis resistance & $35 \Omega$ \\
Rotor inertia & $0.00923 \mathrm{~kg} \mathrm{~m}^{2}$ \\
\hline
\end{tabular}

It is seen from Fig. 8 that the change in the shunt and series capacitors in long-shunt compensation is higher than in short-shunt compensations. This will reflect in a large variation in the duty cycle of the inverter switches to get the overall required range of capacitances.

\section{Optimal capacitance required under varying wind speed and lagging power factor}

When wind speed is increased, the load voltage will also increase and the controllers will take action to make load voltage profile constant. In short-shunt compensation, series capacitor value drops with increasing wind speed to adjust voltage level at a desired value as shown in Fig. 9a. On the other side, Fig. 9b illustrates that the shunt capacitor value requirement is significantly increased with rise in wind speed to adjust voltage profile also for long-shunt compensation.

The increase in wind speed will increase in generator speed and frequency of output voltage. As a result, the controller will try to change the capacitance value to adjust the frequency again. Figure 9c, d illustrates the value of shunt and series capacitors, 
a

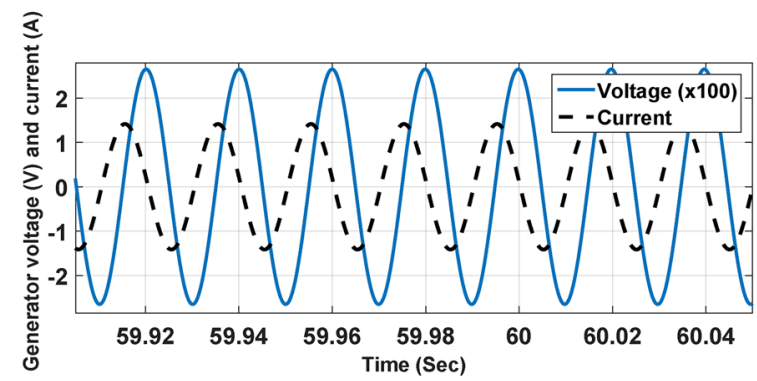

b

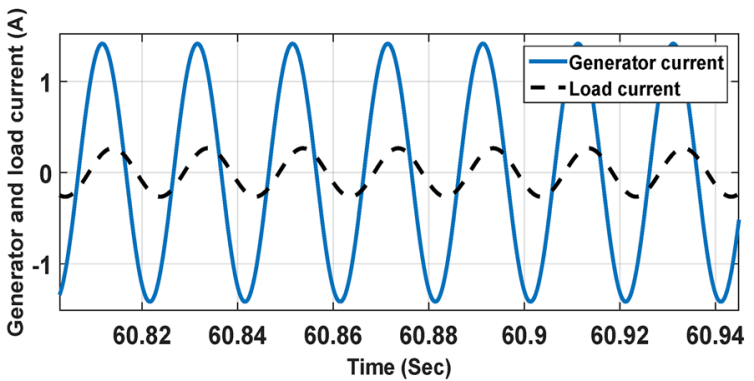

c

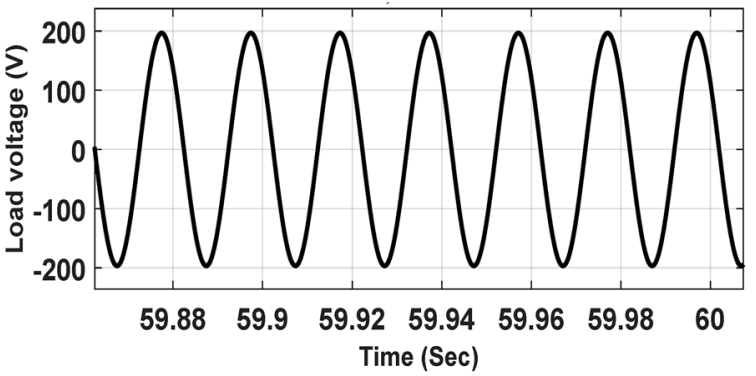

Fig. 11 Simulation results for short-shunt compensation, a generator voltage and current, b generator and load currents and $\mathbf{c}$ load voltage

which are needed to keep generator speed constant in the short- and long-shunt compensations, respectively. In particular, under constant voltage profile, low power factor requires low series capacitor value in the long-shunt compensation; in contrast, low power factor requires high shunt capacitor value in the short-shunt compensation. It is noticed that the variation of load power factor has a very small effect on the values of the shunt and series capacitors.

\section{Experimental results}

A $0.2-\mathrm{kW}, 380-\mathrm{V}$ synchronous reluctance generator is used to demonstrate experimentally the validity of the SERG dynamic model and equivalent circuit. Figure 10 shows the experimental setup picture at the laboratory, where a wind turbine is emulated by using a DC motor. The parameters of the SERG are listed in Table 2. The results are obtained with variable load impedances and power factor. An inductive load of $244 \Omega$ resistance and $0.5 \mathrm{H}$ inductance is used in the test for both short- and long-shunt compensations. 
a

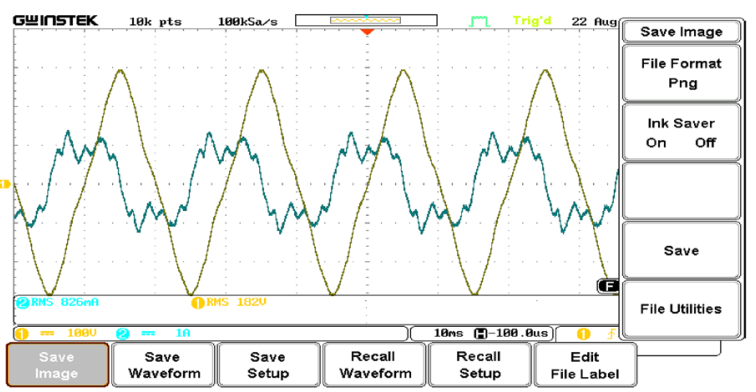

b

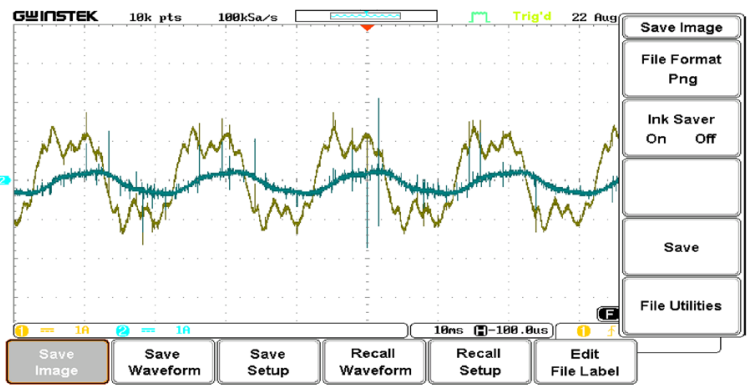

c

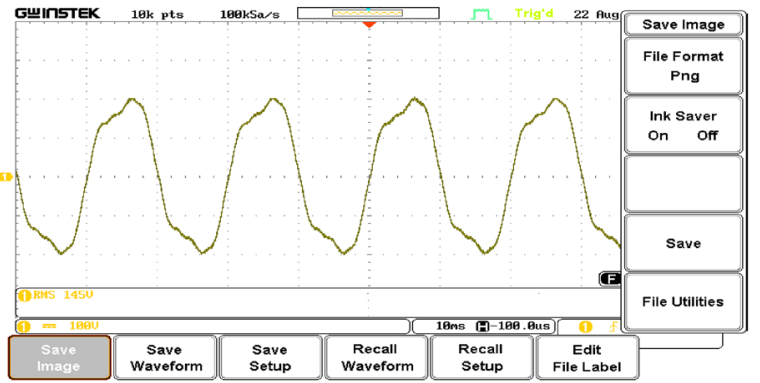

Fig. 12 Experimental results for short-shunt compensation, a generator voltage and current, b generator and load currents and $\mathbf{c}$ load voltage

A single-point test is performed to prove the validity of dynamic models and equivalent circuits of the two configurations (short- and long-shunt compensation). The values of two series and shunt capacitors are inserted in MATLAB Simulink model, and the speed of SERG is adjusted to confirm the value in hardware test by changing the prime mover toque applied on SERG.

For short-shunt compensation, a shunt capacitor of $18 \mu \mathrm{f}$ and a series capacitor of $4 \mu \mathrm{f}$ are used. These capacitors controlled the output phase voltage of the generator to $183 \mathrm{~V}$ (rms) and the generator speed to $1320 \mathrm{rpm}$ (output frequency equals $44 \mathrm{~Hz}$ ). Figures 11 and 12 show the simulation and experimental results for SERG connected to short-shunt configuration.

For long-shunt compensation, a shunt capacitor of $59 \mu \mathrm{f}$ and a series capacitor of $46 \mu \mathrm{f}$ are used. These capacitors controlled the output phase voltage of the generator to $139 \mathrm{~V}$ (rms) and the generator speed to $1230 \mathrm{rpm}$ (output frequency equals 
a

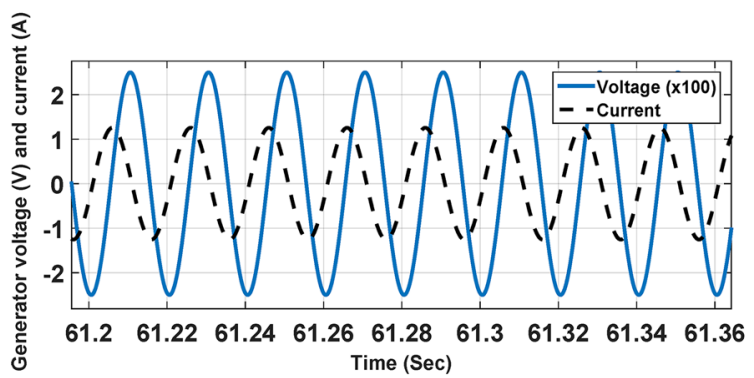

b

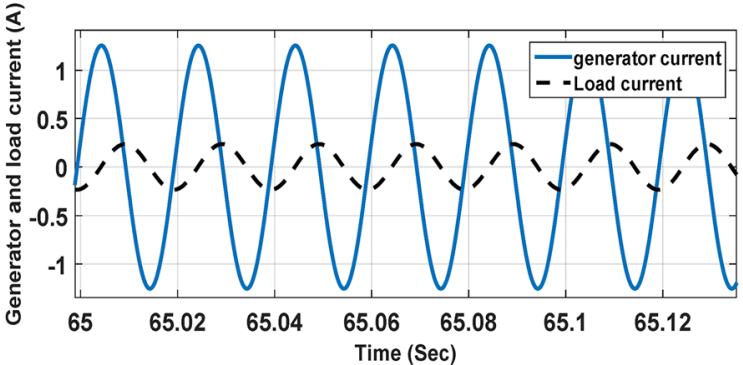

c

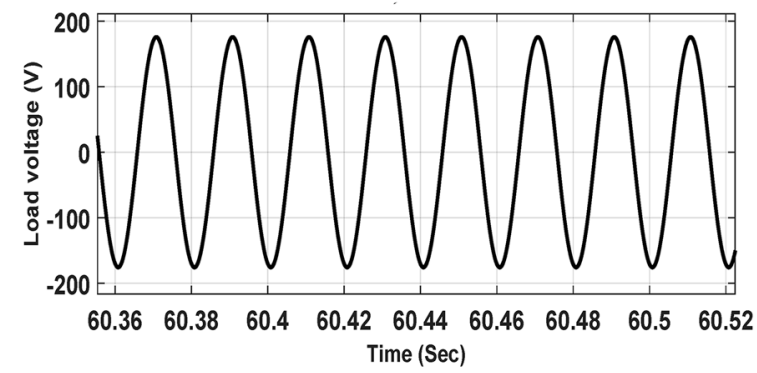

Fig. 13 Simulation results for long-shunt compensation, a generator voltage and current, $\mathbf{b}$ generator and load currents and $\mathbf{c}$ load voltage

$41 \mathrm{~Hz}$ ). Figures 13 and 14 show the simulation and experimental results for SERG connected to long-shunt configuration.

It is noticed that the experimental results have nearly the same RMS value for the generator phase voltage and current and load current as the simulation results, but the generator current is not pure sinusoidal waveform. Table 3 presents percentage of error between experimental and simulation results. Furthermore, there is a good correlation between simulation and experimental results, which validates the dynamic model and supports the assumption made in the model. 


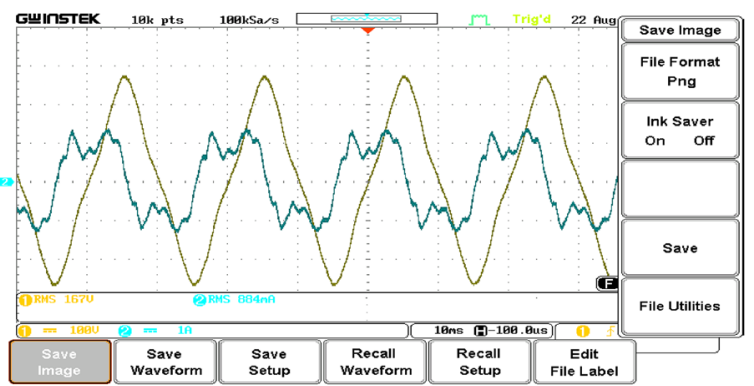

b

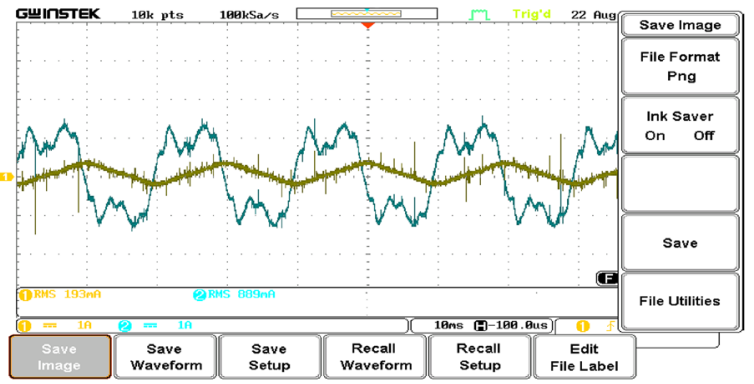

c

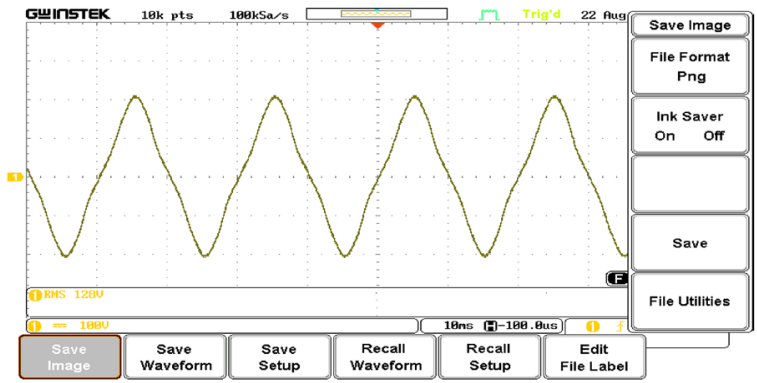

Fig. 14 Experimental results for long-shunt compensation, a generator voltage and current, $\mathbf{b}$ generator and load currents and c load voltage

Table 3 Summarization of results and percentage error

\begin{tabular}{llll}
\hline Compensation & Generator voltage & Generator current & Load current \\
\hline Short-shunt result & & & \\
Simulated & 175.6 & 1.04 & 0.23 \\
Experimental & 183 & 1.1 & 0.26 \\
Error (\%) & 4.2 & 5.4 & 11.5 \\
Long-shunt result & 123.5 & & 0.2 \\
Simulated & 139 & 0.76 & 0.23 \\
Experimental & 11 & 0.88 & 15 \\
Error (\%) & & 13.6 & \\
\hline
\end{tabular}




\section{Conclusions}

This paper presents a control technique to regulate the output voltage and frequency of WDSERG connected to an isolated load. Dynamic model of SERG with excitation capacitors at variable wind speed, load current and power factor is developed. Simulation results for a 1.5-kW WDSERG system are performed to verify the control scheme effectiveness. From the simulation results, it can be proved that the output voltage and frequency of WDSERG could be controlled by two series and shunt switching capacitors with different configurations (long- and short-shunt compensation).

In short-shunt compensation, series capacitor requirement increases as the loading current and power factor increase. However, lower series capacitor is required for high wind speed value. On the other hand, the value of shunt capacitor decreases with increasing load current and power factor. Furthermore, there is a direct relationship between wind speed and shunt capacitor. In the long-shunt case, shunt capacitor value and wind speed value are in direct proportion, but it is inversely proportional to loading current and power factor. On the other side, series capacitor value requirement increases as loading current and power factor increase. However, series value capacitor decreases with increasing wind speed value.

It is observed from the results that the load power factor variation has a more significant effect on the value of the optimal required capacitances with load current variation than changing of wind speed. The values and variation range of shunt and series capacitors for long-shunt compensation are higher than that for short-shunt compensation; these lead to a large variation in the duty cycle of the inverter switches, which requires a complicated control algorithm, and the cost is increased because of the large value of capacitor. Furthermore, long-shunt compensation configuration has higher shunt capacitor current. Hence, short-shunt configuration is the best choice to control the voltage and frequency of SERG.

List of symbols

A: Turbine swept area; $C_{p}$ : Performance coefficient of the turbine; $C_{\mathrm{se},} C_{\text {sh }}$ : Series and shunt capacitors; $i_{d \mu} i_{q l}: d-q$ axes components of the load current; $i_{d s} i_{q s}: d-q$ axes components of the stator current; $L_{d s} L_{q s}: d-q$ axes components of the stator inductance; $P$ : Number of pair poles; $R$ : Radius of the turbine blade; $R_{p} L_{i}$ : Load resistance and inductance; $R_{s}$ : Stator resistance; $T_{\mathrm{e}}$ : Electromagnetic torque; $T_{\mathrm{pm}}$ : Prime mover torque; $v_{c d^{\prime}} v_{c q}: d$-q axes components of the capacitor voltage; $v_{d \prime} v_{q j}: d-q$ axes components of the load voltage; $v_{d s} v_{q s}: d-q$ axes components of the stator terminal voltage; $V_{w}:$ Wind speed; $X_{d u n}$ : Unsaturated value of $d$-axis synchronous reactance; $X_{q}: q$-axis synchronous reactance; $\beta$ : Moment of inertia; $J$ : Blade pitch angle; $\lambda$ : Tip speed ratio; $\lambda_{d s^{\prime}} \lambda_{q s^{\prime}}: d-q$ axes components of the stator flux linkage; $\rho$ : Air density; $\omega_{0}$ : Rated (base) synchronous speed; $\omega_{r}$ : Angular speed of rotor; $\omega_{t}$ : Rotor blade speed.

\section{Abbreviations}

DFIG: Doubly fed induction generator; MPPT: Maximum power point tracking; PMSG: Permanent magnet synchronous generator; SEIG: Self-excited induction generator; SERG: Self-excited reluctance generator; WDSERG: Wind-driven selfexcited reluctance generator; WECS: Wind energy conversion system.

Acknowledgements

Not applicable.

\section{Authors' contributions}

JSS contributed in the design, the creation of the software used in the work and interpretation of the results of the work, performed the experimental work and drafted the final manuscript. HMY contributed in the design, analysis and interpretation of the results of the work and drafted the final manuscript. HHH contributed in the conception, analysis, the creation of the software used in the work and interpretation of the results of the work and revised the final manuscript. FI contributed in the conception and interpretation of the results of the work and revised the final manuscript. All authors read and approved the final manuscript.

Funding

Not applicable. 
Availability of data and materials

Not applicable.

\section{Declarations}

Competing interests

The authors declare that they have no competing interests.

\section{Author details}

${ }^{1}$ Electrical Engineering Department, Faculty of Engineering, Ahram Canadian University, Giza, Egypt. ${ }^{2}$ Electrical Power Engineering Department, Faculty of Engineering, Cairo University, Giza, Egypt.

Received: 23 November 2020 Accepted: 10 March 2021

Published online: 23 March 2021

\section{References}

1. Abu-Elhaija W, Muetze A (2013) Self-excitation and stability at speed transients of self-excited single-phase reluctance generators. IEEE Trans Sustain Energy 4(1):136-144

2. Allam S, EL-Khazendar M, Osheiba A (2006) Dynamic analysis of a self-excited single-phase reluctance generator. Electr Power Components Syst 34(7):725-738

3. Alolah A (1991) Capacitance requirements for three-phase self-excited reluctance generator. IEE Proc Gener Transm Distrib 138(3):193-198

4. Alolah A (1992) Steady-state operating limits of three phase self-excited reluctance generator. IEE Proc Gener Transm Distrib 139(3):261-268

5. Al-Saffar M, Nho E, Lipo T (1998) Controlled shunt capacitor self-excited induction generator. In: The 33rd IEEE IAS annual meeting, pp 1486-1490

6. Amirat Y, Benbouzid M, Bensaker B et al (2007) The state of the art of generators for wind energy conversion systems. Electromotion 14(4):163-172

7. Attoui l, Omeiri A (2014) Modeling, control and fault diagnosis of an isolated wind energy conversion system with a self-excited induction generator subject to electrical faults. Energy Convers Manag 82:11-26

8. Ayodele T, Ogunjuyigbe A (2015) Wind energy resource, wind energy conversion system modelling and integration: a survey. Int J Sustain Energy 3(10):657-671

9. Ayodele T, Ogunjuyigbe A, Adetokun B (2017) Optimal capacitance selection for a wind-driven self-excited reluctance generator under varying wind speed and load conditions. Appl Energy 190:339-353

10. Bansal R (2005) Three-phase self-excited induction generators: an overview. IEEE Trans Energy Convers 20(2):292-299

11. Ben-Hail N, Rabinovici R (2001) Three-phase autonomous reluctance generator. IEE Proc Electr Power Appl 148(5):438-442

12. Blaabjerg F, Teodorescu R, Liserre M et al (2006) Overview of control and synchronization for distributed power generation systems. IEEE Trans Ind Electron 53(5):1398-1409

13. Carranza O, Figueres E, Garcera G et al (2013) Analysis of the control structure of wind energy generation systems based on a permanent magnet synchronous generator. Appl Energy 103:522-538

14. Chan T (1992) Steady state analysis of a three-phase self-excited reluctance generator. IEEE Trans Energy Convers $7(1): 223-230$

15. Cheng M, Zhu Y (2014) The state of the art of wind energy conversion systems and technologies: a review. Energy Convers Manag 88:332-347

16. Hassine IM, Naouar MW, Mrabet-Bellaaj N (2015) Predictive control strategies for wind turbine system based on permanent magnet synchronous generator. ISA Trans 62:73-80

17. Hossain M, Ali M (2015) Future research directions of the wind turbine generator system. Renew Sustain Energy Rev 49:481-489

18. Iwanski G, Koczara W (2008) Autonomous power system for island or grid-connected wind turbines in distributed generation. Eur Trans Electr Power 18:658-673

19. Krause P, Wasynczuk O, Sudhoff S (1995) Analysis of electric machinery. IEEE, Piscataway, NJ

20. Malik N, Haque S (1986) Steady state analysis and performance of an isolated self-excited induction generator. IEEE Trans Energy Convers 1(3):134-140

21. Meenakshi R, Muthu R (2013) Doubly fed induction generator for wind energy conversion system—a survey. In: Proceedings of the international conference on energy efficient technologies for sustainability (ICEETS), pp 617-628

22. Meo S, Zohoori A, Vahedi A (2016) Optimal design of permanent magnet flux switching generator for wind applications via artificial neural network and multi-objective particle swarm optimization hybrid approach. Energy Convers Manag 110:230-239

23. Mohamadien A, Rahim Y, Alkhalaf A (1990) Steady-state performance of self-excited reluctance generators. IEE Proc Electr Power Appl 137(5):293-298

24. Naidu N, Singh B (2016) Experimental implementation of doubly fed induction generator-based standalone wind energy conversion system. IEEE Trans Ind Appl 52(4):3332-3339

25. Obe E, Anih L (2010) Influence of rotor cage on the performance of a synchronous reluctance generator. Electr Power Compon Syst 38(8):960-973

26. Ogunjuyigbe A, Jimoh A, Nicolae D et al (2010) Analysis of synchronous reluctance machine with magnetically coupled three-phase windings and reactive power compensation. IET Electr Power Appl 4(4):291-303 
27. Ojo O, Wu Z (1997) Performance characteristics of dual winding reluctance generators. IEE Proc Electr Power Appl 144(6):461-468

28. Pena R, Clare J, Asher G (1996) A doubly fed induction generator using back-to-back PWM converters supplying an isolated load from a variable speed wind turbine. IEE Proc Electr Power Appl 143(5):380-387

29. Poultangari I, Shahnazi R, Sheikhan M (2012) RBF neural network based PI pitch controller for a class of 5-MW wind turbines using particle swarm optimization algorithm. ISA Trans 51(5):641-648

30. Rahim Y, Fletcher J, Hassanain N (2010) Performance analysis of salient-pole self-excited reluctance generators using a simplified model. IET Renew Power Gener 4(3):253-260

31. Rahim Y, Al-Sabbagh A (1997) Controlled power transfer from wind driven reluctance generator. IEEE Trans Energy Convers 12(4):275-281

32. Rahim Y, Alyan M (1991) Effect of excitation capacitors on transient performance of reluctance generators. IEEE Trans Energy Convers 6(4):714-720

33. Rahim Y, Mohamadein A, Al-khalaf A (1990) Comparison between the steady state performance of self-excited reluctance and induction generators. IEEE Trans Energy Convers 5(3):519-525

34. Tischer C, Tibola J, Scherer $L$ et al (2017) Proportional-resonant control applied on voltage regulation of standalone SEIG for micro-hydro power generation. IET Renew Power Gener 11(5):593-602

35. Wang L, Wang Y (1999) Dynamic performance and minimum loading effects of an isolated self-excited reluctance generator. In: IEEE/PES winter meeting, pp 13-18

36. Wang Y, Bianchi N (2018) Investigation of self-excited synchronous reluctance generators. IEEE Trans Ind Appl 54(2):1360-1369

37. Yassin H, Hanafy H, Hallouda M (2016) Design and implementation of PI controllers of direct drive PMSG wind turbine system tuned by linearized biogeography-based optimization technique. In: The 42nd annual conference of the IEEE Industrial Electronics Society, pp 4072-4077

38. Yenduri K, Sensarma P (2016) Maximum power point tracking of variable speed wind turbines with flexible shaft. IEEE Trans Sustain Energy 7(3):956-965

\section{Publisher's Note}

Springer Nature remains neutral with regard to jurisdictional claims in published maps and institutional affiliations.

\section{Submit your manuscript to a SpringerOpen ${ }^{\circ}$ journal and benefit from:}

- Convenient online submission

- Rigorous peer review

- Open access: articles freely available online

- High visibility within the field

Retaining the copyright to your article

Submit your next manuscript at $\boldsymbol{\nabla}$ springeropen.com 